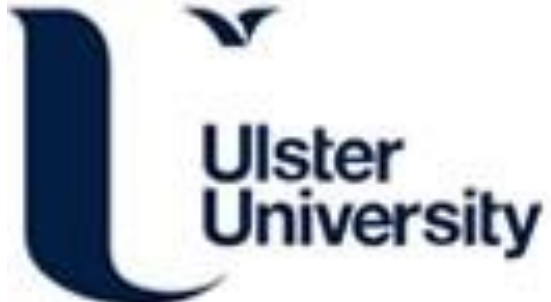

\section{Geobacillus Activities in Soil and Oil Contamination Remediation}

Banat, I., \& Marchant, R. (2011). Geobacillus Activities in Soil and Oil Contamination Remediation. In Endospore-forming Soil Bacteria (pp. 259-270). Springer.

Link to publication record in Ulster University Research Portal

Published in:

Endospore-forming Soil Bacteria

Publication Status:

Published (in print/issue): 01/01/2011

\section{Document Version}

Publisher's PDF, also known as Version of record

\section{General rights}

Copyright for the publications made accessible via Ulster University's Research Portal is retained by the author(s) and / or other copyright owners and it is a condition of accessing these publications that users recognise and abide by the legal requirements associated with these rights.

\section{Take down policy}

The Research Portal is Ulster University's institutional repository that provides access to Ulster's research outputs. Every effort has been made to ensure that content in the Research Portal does not infringe any person's rights, or applicable UK laws. If you discover content in the Research Portal that you believe breaches copyright or violates any law, please contact pure-support@ulster.ac.uk. 


\title{
Chapter 13 \\ Geobacillus Activities in Soil and Oil Contamination Remediation
}

\author{
Ibrahim M. Banat and Roger Marchant
}

\subsection{Introduction}

The genus Geobacillus has only existed since the year 2001, when it was proposed by Nazina et al. (2001). That is not to say, however, that we were unaware of this group of organisms, since Nazina et al. built the new genus around previously described members of the genus Bacillus that had been placed in genetic group $\mathrm{V}$ by Ash et al. (1991), using 16S rRNA gene sequence information. Nazina et al. used Bacillus stearothermophilus, a well known and extensively investigated thermophilic organism, as the type species for the new genus and transferred a number of related thermophilic species of Bacillus into Geobacillus. Adding to this core of Geobacillus species, Nazina et al. (2001) proposed two new species that they had isolated from deep oil reservoirs. Since that original description of the genus with eight species a further nine, from a variety of sources, have been described. These include G. toebii from composting plant material (Sung et al. 2002), G. debilis from temperate soil environments (Banat et al. 2004), Geobacillus pallidus which was originally proposed as Bacillus pallidus by Scholz et al. (1987) and reassigned by Banat et al. (2004), G. vulcani (proposed as Bacillus vulcani, Caccamo et al. 2000) from marine geothermal sources and transferred to Geobacillus by Nazina et al. (2004) and G. tepidamans (Schäffer et al. 2004) from geothermal sources in Austria and Yellowstone National Park. A complete listing of current valid species for the genus Geobacillus can be found at http://www.bacterio.cict.fr/g/geobacillus.html. What is clear from this listing of species is that members of the genus can be isolated from a wide variety of different environmental sources. Some of these situations are those where we would expect to find obligately thermophilic bacteria, i.e., geothermally active areas, both terrestrial and marine. The observation that Geobacillus spp. also occur in composting plant material is logical, since this is another environment where temperatures up to $60^{\circ} \mathrm{C}$ are readily experienced by

I.M. Banat $(\bowtie)$ and R. Marchant

School of Biomedical Sciences, Faculty of Life and Health Sciences, University of Ulster, Coleraine, BT52 1SA, Northern Ireland, UK

e-mail: IM.Banat@ulster.ac.uk 
microorganisms. On the other hand, the recovery of quite high concentrations of thermophilic Geobacillus spp. from temperate soil environments, and not just in the surface layers but also at considerable depth, is much harder to explain (Marchant et al. 2002a, b). Traditionally, the search for thermophilic microorganisms has focused on hot environments, but we must now examine a wider range of potential habitats and explore the means by which thermophiles can be transported to such areas if they are unable to grow and reproduce in the conditions found there. The first requirement of any such investigation is to establish the actual and potential activities of these thermophiles.

\subsection{The Growth and Metabolism of Geobacillus Species}

A starting point is to look at the description of the genus published by Nazina et al. (2001). The organisms were described as rod-shaped and producing one endospore per cell, with cells occurring either singly or in short chains and being motile by means of peritrichous flagella. Interestingly, subsequent observations of Geobacillus spp. have shown that extremely long cells may be produced under some conditions (Marchant et al. 2002a). These cells appear to lack cross walls and are therefore not chains of short rods, but they are subsequently capable of dividing to yield normalsized rods through a process of progressive binary fission. The factors controlling this behaviour have not yet been identified. Cells have a Gram-positive cell wall structure but may stain Gram-variable. They are chemo-organotrophs that are aerobic or facultatively anaerobic, using oxygen as the terminal electron acceptor - replaceable by nitrate in some species. Geobacillus spp. are obligately thermophilic with a growth range of $37-75^{\circ} \mathrm{C}$ and optima of $55-65^{\circ} \mathrm{C}$, and they are neutrophilic with a growth range of $\mathrm{pH}$ 6.0-8.5. The $\mathrm{G}+\mathrm{C}$ content of DNA is 48.2-58 mol\% with 16S rRNA gene sequence similarities of higher than $96.5 \%$ (Nazina et al. 2001).

From the above definition of the genus it would appear that any Geobacillus spp. existing in subsurface soil layers in temperate regions would be non-growing. The standard methods for evaluating growth of bacteria under laboratory conditions involve setting up cultures either on solid media or in liquid culture at appropriate temperatures and observing growth over relatively short periods of time. This does not exclude the possibility that organisms may be growing and dividing extremely slowly. To test this, Marchant et al. (2006) employed a molecular technique to examine gene expression over a temperature range in $G$. thermoleovorans. A gene not expected to be present in other thermophilic bacteria, alkane hydroxylase, was selected and the level of expression of this gene was determined at temperatures above and below the permissive growth temperature of $40^{\circ} \mathrm{C}$, using reverse transcriptase PCR techniques. The system was first established in pure culture conditions and subsequently in soil microcosms. It was clear from this work that the alkane hydroxylase gene was readily expressed at or above $40^{\circ} \mathrm{C}$, but that expression could not be detected below this temperature. These data seemed to eliminate 
the hypothesis that aerobic growth was taking place in sub-surface soil layers. There did, however, remain the possibility that $G$. thermoleovorans, which possesses a full set of denitrification genes, could grow and divide anaerobically at lower temperatures in the lower soil layers. This hypothesis was tested by examining the denitrification activity of the organism over a temperature range that spanned the permissive growth temperature (Pavlostathis et al. 2006). Once again, activity was detectable only above $40^{\circ} \mathrm{C}$ - seemingly eliminating the likelihood of growth and cell division taking place at ambient temperatures in soil.

One interesting observation connected with $G$. toebii was recorded by Rhee et al. (2000, 2002) who described a bacterium, "Symbiobacterium toebii" that has a symbiotic relationship requiring the products of cell lysis of $G$. toebii to allow growth. Further work (Kim et al. 2008) has now been carried out to characterize the cell lysis and metabolic products involved in this symbiosis, although complete identification of the molecules has not been made. This rather unusual symbiotic relationship raises the question of whether other Geobacillus spp. could be involved in similar interactions and whether cell lysis on a scale sufficient to provide metabolites for a symbiont is likely to occur during growth. Pavlostathis et al. (2006) have carried out an extensive study of the growth of G. thermoleovorans in batch and continuous flow fermentation systems. These studies have shown that under conditions of high growth rate followed by substrate exhaustion, not just of carbon but of other nutrients as well, extensive cell lysis takes place and that beyond a certain point of commitment - reinstatement of the nutrient level fails to prevent lysis. Flow cytometry studies carried out at the same time demonstrated that at these high growth rates the death rate was correspondingly high. Since G. toebii and $S$. toebii have been isolated from thermophilic fermentation of plant material, it is quite possible that cell lysis sufficient to sustain the symbiotic relationship does actually take place.

\subsection{Hydrocarbon Degradation by Geobacillus Species}

Many of the species of Geobacillus have been isolated from oilfields and more specifically from deep oil wells. Not surprisingly, these organisms show welldeveloped abilities to degrade a range of hydrocarbons of different chain lengths. The ability of all Geobacillus spp. to degrade such molecules has not been fully investigated, and thus alkane-degrading activity has not been reported for $G$. lituanicus, G. pallidus, G. tepidamans and G. thermoglucosidasius, with G. debilis reported to have only weak ability (Banat et al. 2004). The absence of a reported alkane-degrading activity does not necessarily imply the inability of the organism in this activity, but may simply represent the fact that it has not been examined. We can say therefore that hydrocarbon degradation is a widespread capability of members of the genus Geobacillus, but may not be universal. There have been few reports on the range of hydrocarbons utilized by particular organisms. Marchant et al. (2002b) examined the ability of soil isolates of G. caldoxylosilyticus, G. toebii 
and $G$. thermoleovorans, to utilize a range of alkanes from pentane to nonadecane, including hexane, heptane, dodecane, hexadecane and octadecane and the polyaromatic hydrocarbons (PAHs) naphthalene, anthracene and kerosene. The patterns of utilization were dissimilar between the different species, and different strains of $G$. thermoleovorans also differed in their abilities to use these substrates. There was not even a clear differentiation between use of short-chain and longer-chain alkanes. The main conclusion to be drawn from this work was that the PAHs are more refractory to degradation. In a recent study (Sood and Lal 2008) it has been shown that a strain of Geobacillus kaustophilus has the ability to degrade paraffinic hydrocarbons (waxes) that create problems in some oilfields through deposition in pipe work. Hydrocarbons in the range $\mathrm{C}_{20}-\mathrm{C}_{30}$ are broken down by this organism, which raises the possibility that the organism can be used to clean and maintain the systems in problematic oilfields.

Feng et al. (2007) have recently reported the presence of a plasmid-borne putative monooxygenase gene in Geobacillus thermodenitrificans NG80-2, which is responsible for the conversion of $\mathrm{C}_{15}-\mathrm{C}_{36}$ alkanes into the corresponding primary alcohols. Crude oil used as the sole carbon source for growth led to a 120-fold increase in gene transcription. The gene is somewhat unusual in that it has only $33 \%$ sequence identity with DBT-5,5'-dioxide monooxygenase of Paenibacillus sp. A11-2 (Ishii et al. 2000) and no similarity with other alkane monooxygenases.

Feitkenhauer et al. (2003) have reported the use of $G$. thermoleovorans in a continuous-flow fermentation system to degrade phenol at $65^{\circ} \mathrm{C}$, but this was a laboratory-scale set of experiments and there have been no other studies of alkane degradation either at a laboratory scale or at a larger industrial scale. One feature of other hydrocarbon-degrading bacteria is the ability to produce biosurfactant molecules that can make the hydrocarbons more amenable to degradation. There have, however, not been any reports of Geobacillus spp. producing biosurfactants, and we have never observed evidence of such production in any of our cultures.

\subsection{The Genetics of Geobacillus}

A considerable amount of genetic information exists for members of the genus Geobacillus since complete genome sequences have been published for G. kaustophilus HTA426 (Takami et al. 2004a) and G. thermodenitrificans NG80-2 (Feng et al. 2007), and draft sequences for G. stearothermophilus strain 10 (prepared at the University of Oklahoma) and G. thermoleovorans T80 (University of Ulster) are available in the public databases. Detailed examination of the genome sequences for these organisms has offered interesting insight into thermophilic adaptation in Geobacillus spp. Since they are closely related to a wide range of mesophilic, aerobic endospore-formers, different groups of researchers anticipated that there would be clear indications of specific adaptation to growth at high temperature in the genome sequences. These expectations have been, to a great extent, frustrated. A number of basic mechanisms for thermophily can be postulated and tested: these 
include the lateral transfer of specific genes from other thermophilic bacteria such as Archaea, the specific modification of the mesophilic gene sequences to produce more thermostable gene products and the use of chaperonins to protect gene products from damage. The only published analyses are those of Takami et al. (2004b) and Feng et al. (2007). These workers found it extremely difficult to identify specific characteristics in the genomes of Geobacillus spp. that could be linked to thermophily. The published genome of G. kaustophilus is $3.54 \mathrm{Mb}$ in size and contains $37 \%$ of the genes $(1,308)$ shared with other of mesophilic, aerobic endospore-formers. Very few of the genes that are common with mesophiles, particularly those in the core metabolic pathways, show any significant sequence variation and very few of the genes can be identified as orthologues of genes from other thermophilic organisms such as members of the Archaea. This situation holds also for the genome of $G$. thermoleovorans (unpublished results). An identifiable characteristic of the Geobacillus spp. is, however, the presence of large numbers of transposon sequences (55 in G. thermodenitrificans, 80 in G. kaustophilus), and these are in contrast with low numbers in Bacillus subtilis, B. cereus and B. anthracis (Takami et al. 2004b; Feng et al. 2007). The presence of these sequences indicates that lateral gene transfer may have been an important feature for these organisms and may also suggest that active evolution of the species is still taking place. Analysis of the draft genome sequence for G. thermoleovorans T80 (Matzen et al. unpublished) has led to the identification of two cassettes of genes for RAMP (Repair Associated Mysterious Proteins) that are not present in the genomes of mesophilic endospore-formers and which do not appear in the complete genomes of G. kaustophilus or G. thermodenitrificans. These groups of genes seemed to be potentially important for the mechanisms of thermophily, and therefore further wet laboratory experiments were carried out on the genomes of the previously sequenced strains of G. kaustophilus and G. thermodenitrificans. This work showed that the RAMP cassettes are indeed present in these organisms and had been either missed during the original shotgun sequencing or had been eliminated during the final assembly of the genome (Matzen et al. unpublished). The recent identification of CRISPRs (clustered regularly interspaced short palindromic repeats) in prokaryotic genomes and their association with 45 CRISPR-Associated (Cas) protein families can explain how the RAMP cassettes (which are now known to be Cas genes) could become eliminated during genome assembly (Haft et al. 2005). What role these Cas genes play, and whether they are important for thermophily remain matters for conjecture. There is little evidence from the analysis of the Geobacillus genomes to support the view that large numbers of key genes have been laterally transferred from other thermophilic organisms, particularly members of the Archaea, or that base substitution or coding changes have produced more temperature-resistant versions of pre-existing mesophile genes. An interesting question is, therefore, not so much how these organisms grow at high temperatures, but why they do not grow at the same temperatures as mesophiles?

The genetic basis of alkane degradation has been extensively reported for a number of different bacteria, including Pseudomonas putida (van Beilen et al. 2001), Acinetobacter (Ratajczak et al. 1998a, b) and Rhodococcus erythropolis 
(Whyte et al. 2002). In these studies it has been shown that the components of the alkane degradation system are organized into two operons, with an alkane monooxygenase catalysing the first step and with up to four different gene homologues present (alkB1-alkB4). Marchant et al. (2006) used sequence information from the genes in Rhodococcus spp. and Prauserella rugosa to construct degenerate primers for a segment of the alkB gene in $G$. thermoleovorans T80. The objective of this approach was to use the expression of the alkane monooxygenase gene as a measure of the metabolic activity of the bacterium in soil conditions at various temperatures. The culture work had suggested that there was no detectable growth at temperatures below $40^{\circ} \mathrm{C}$ in laboratory conditions. This observation was confirmed by molecular studies using reverse transcriptase PCR methods - with no expression of the gene detectable at temperatures below $40^{\circ} \mathrm{C}$, but clear evidence of expression at all higher temperatures. Since many of the species of Geobacillus have been isolated from high temperature environments, it is not surprising to find that they only grow at these temperatures, but what is paradoxical is that large numbers of these seemingly obligate thermophiles can be recovered from temperate soils where the temperature can never reach the growth-permissive range.

\subsection{The Potential of Geobacillus Species for Remediation of Hydrocarbon-Contaminated Sites}

The first real indication that thermophilic bacteria might have significant roles in the remediation of hydrocarbon-contaminated sites came from the application of a process for the steam stripping of volatile hydrocarbons from soil (Newmark and Aines 1998); this was developed at the Lawrence Livermore National Laboratory in America. The process involved the injection of steam through pipes inserted into the contaminated site and the collection of the volatile hydrocarbons displaced by the steam. The system was capable of removing large proportions of the contaminants but, as a corollary, elevated the temperature of the whole site; this elevated temperature persisted for extended periods (measured in weeks) following cessation of the steam injection. It was observed that levels of hydrocarbon contamination continued to decline during this period, and microbiological investigations established that thermophilic hydrocarbon-degrading bacteria were responsible. These observations support the view that elevating the temperature of a contaminated site could promote the activity of thermophiles and facilitate the process of bioremediation.

Any process of bioremediation requires a number of components to be in place, including appropriate nutritional status and the presence of active microorganisms to achieve the remediation. In many instances, specific steps are taken to ensure suitable conditions through the addition of nutrients and by bioaugmentation with selected and adapted organisms. In the case of the steam-stripping system, the temperature increase had caused the growth stimulation of existing microorganisms in the site and no bioaugmentation was undertaken. 
Fig. 13.1 Time course for $2 \%(\mathrm{v} / \mathrm{v}) n$-hexadecane degradation in soil microcosms incubated at $60^{\circ} \mathrm{C}$ and room temperature. Abbreviation used: $S S$ sterile soil; NSS non-sterile soil; NPK Augmented with nitrogen, phosphorus and potassium and $R T$ room temperature

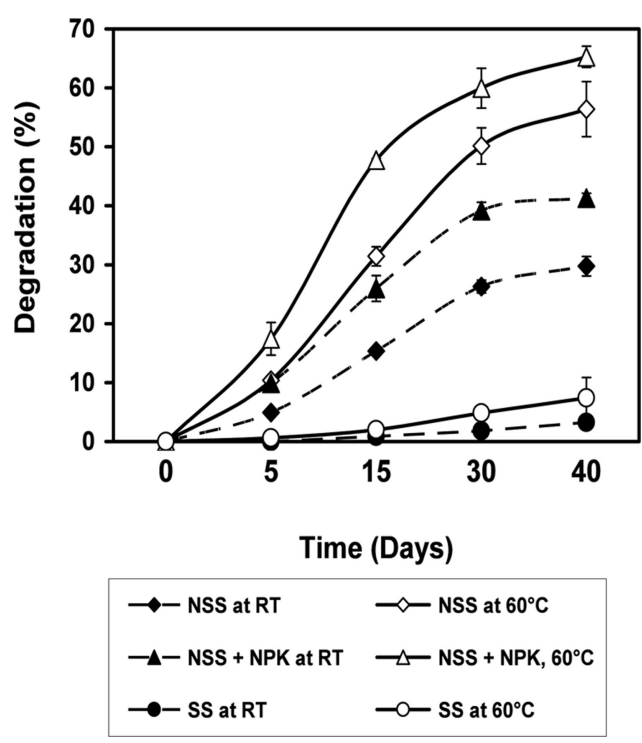

The observations from contaminated sites are supported by data on $n$-hexadecane degradation in various microcosm treatments. These were set up at room temperature and at $60^{\circ} \mathrm{C}$ in sterile and non-sterile soils containing $2 \%(\mathrm{v} / \mathrm{v}) n$-hexadecane, and either with or without supplements of additional nutrient elements. The results (Fig. 13.1) showed that the controls containing sterile soil had minimal losses of hexadecane over a period of 40 days; abiotic loss of alkane in sterile soil owing to physico-chemical processes such as photo-oxidation, volatilization and evaporation were shown to be insignificant. In contrast, the microcosms containing non-sterile soil showed progressive losses of hexadecane over the incubation period, and nutrient supplementation produced enhanced degradation at both room temperature and $60^{\circ} \mathrm{C}$. These results indicated that the soil, although originally uncontaminated, contained an indigenous microbial population capable of supporting bioremediation and also confirmed the ubiquity of hydrocarbon-degrading microorganisms. Interestingly, these data suggested that in this cool soil there existed a community not only of mesophilic alkane degraders but also thermophilic degraders. What was also clear is that degradation at $60^{\circ} \mathrm{C}$, reaching more than $65 \%$, was considerably greater and more rapid than that at room temperature. In parallel with the degradation there was an increase in microbial numbers, with thermophiles increasing about 10-fold while the mesophile numbers only doubled (Table 13.1; Marchant et al. 2006). It should be noted, however, that the initial numbers of mesophiles were two orders of magnitude greater than those of the thermophiles. These results demonstrated that degradation of alkanes at ambient temperature is probably carried out by mesophilic bacteria, but that thermophiles are capable of achieving higher levels of degradation at appropriate temperatures. 
Table 13.1 Viable cell counts for mesophilic and thermophilic bacteria taken from soil microcosms at 0 and 40 days

\begin{tabular}{llll}
\hline Treatments & & $\begin{array}{l}\text { (CFU/g of soil) } \\
\text { at room temp. }\end{array}$ & $\begin{array}{l}(\mathrm{CFU} / \mathrm{g} \text { of soil) } \\
\text { at } 60^{\circ} \mathrm{C}\end{array}$ \\
\hline At zero time & & & \\
1 & SS & ND & ND \\
2 & NSS & $9.5 \times 10^{5}$ & $1.2 \times 10^{4}$ \\
3 & NSS + NPK & $7.5 \times 10^{5}$ & $2.0 \times 10^{4}$ \\
After 40 days & & ND & ND \\
4 & SS & $1.3 \times 10^{6}$ & $8.5 \times 10^{4}$ \\
5 & NSS & $1.5 \times 10^{6}$ & $2.1 \times 10^{5}$ \\
6 & NSS + NPK &
\end{tabular}

Results are means of five replicates (Marchant et al. 2006).

SS sterile soil, NSS non-sterile soil, NPK nitrogen, potassium and phosphorous additive, ND no colonies detected.

Fig. 13.2 Time course for $2 \%$ (v/v) $n$-hexadecane degradation in soil microcosms incubated at $60^{\circ} \mathrm{C}$ and room temperature with and without augmentation with Geobacillus thermoleovorans $\mathrm{T} 80$

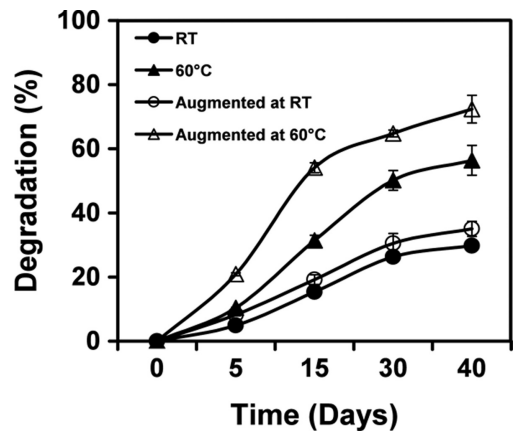

Further microcosm experiments were carried out, in which non-sterile soils containing hexadecane were augmented with $G$. thermoleovorans T80, then incubated at ambient temperature and $60^{\circ} \mathrm{C}$; the latter is optimum for this species (Perfumo et al. 2007). The results (Fig. 13.2) showed higher hexadecane degradation at the higher temperature, and this was significantly increased by augmentation with the bacterium $(>70 \%)$; it was less than approximately half this amount for those kept at ambient temperature, where augmentation had no significant effect on the amount of degradation. G. thermoleovorans T80 was isolated from a similar soil (i.e. it was an autochthonous organism) and has been shown to have no apparent activity at temperatures below $40^{\circ} \mathrm{C}$. Being an autochthonous soil strain was an additional advantage, as that probably helped it to avoid the survival difficulties faced by exogenous microorganisms when introduced to the soil.

In general the above results demonstrated that, irrespective of the treatment, all the microcosms incubated at $60^{\circ} \mathrm{C}$ had hydrocarbon degradation levels approximately twofold higher than those of microcosms kept at ambient temperature. This indicated that increased operating temperatures might significantly enhance natural attenuation in soil, by removal of contaminants from the soil particles by mobilizing them and increasing their solubilities. Moreover, the response of the indigenous 
microbial population at the elevated temperature showed the activation of a community of thermophilic degraders, which suggested an intrinsic potential for natural attenuation in such cool soils through thermally enhanced bioremediation techniques.

The supplementing of soils with limiting nutrients or their augmentation with thermophilic Geobacillus spp. produced additional degradation, resulting in a maximum of $>70 \%$ removal of $n$-hexadecane within a 40 -day period. Thermally enhanced bioremediation may therefore reduce in situ remediation treatment times or be used as a complementary treatment to follow other physical techniques. Further investigation into the most cost-effective methods to provide the energy needed for soil heating, and augmentation procedures to stimulate the process, remain to be carried out.

\subsection{Geographical Distribution of Geobacillus Species}

A critical question to be answered, therefore, if such remediation processes are to be more widely exploited, is whether we can be certain that hydrocarbon-degrading thermophiles are reliably present at every site. Basic studies of the distribution of these organisms, since we know that they are unable to grow at temperatures below $40^{\circ} \mathrm{C}$, assume greater importance in this context and will allow us to know whether we can expect every site to contain them, without specific testing.

Since it seemed that the relatively large numbers of Geobacillus spp. found in sub-surface regions of temperate soils ( $<10^{4} / \mathrm{g}$ soil Marchant et al. 2002b) could not come from growth in situ, the possible input from other sources was investigated. Surprisingly, significant numbers of thermophiles are deposited annually through rainfall, and the population structure of these organisms differs markedly from the population of purely airborne thermophiles (Marchant et al. 2008). This population structure difference between airborne and rainwater bacteria, and the fact that numbers of organisms in rainfall cannot be correlated with wind direction or with intensity of rainfall, support the hypothesis that these are not airborne bacteria washed out of the air by rain. If this is the case then we must look more widely for the sources of thermophiles. In the southern part of the Mediterranean region, and elsewhere in the world, atmospheric dust is periodically precipitated dry. This dust originates from different desert regions of the world, with the major flow being westwards across the Atlantic Ocean to the Caribbean and southern states of the United States. There is a smaller subsidiary flow northwards across Europe, coming from the Sahel-Sahara region of Africa (Griffin 2007); and preliminary examination of samples of such dust from Greece and Turkey has shown populations of thermophilic bacteria that are readily cultivable from the dust and that can be identified as organisms closely related to existing Geobacillus spp. (Marchant and Perfumo unpublished results). Further work is necessary to describe these organisms fully and to link them to the sources of the dust in the Sahel-Sahara region of Africa. At this time, however, it does seem likely that the thermophiles deposited by rainfall in Northern Europe have come from dust storms generated in Africa and 
that they have been transported in the upper atmosphere. If this is the case, we can be reasonably certain that hydrocarbon-degrading thermophilic bacteria will be ubiquitous in environments where this deposition occurs, and might be exploited directly for bioremediation without the need for bioaugmentation.

\subsection{Conclusion}

Members of the Geobacillus appear to be present in most soil environments - even those never experiencing elevated temperatures. Most have some ability to grow on hydrocarbons and may therefore be exploited in bioremediation processes. In such a process the need for bioaugmentation may only be necessary to increase the initial rate of activity. Biostimulation, on the other hand, may have an important role when depending on Geobacillus spp. in bioremediation processes. The hydrocarbondegrading abilities of Geobacillus spp. may therefore find useful bioremediation applications in a variety of different situations in the future.

\section{References}

Ash C, Farrow JAE, Wallbanks S, Collins MD (1991) Phylogenetic heterogeneity of the genus Bacillus revealed by comparative analysis of small-subunit-ribosomal RNA sequences. Lett Appl Microbiol 13:202-206

Banat IM, Marchant R, Rahman TJ (2004) Geobacillus debilis sp. nov., a novel obligately thermophilic bacterium isolated from a cool soil environment and reassignment of Bacillus pallidus to Geobacillus pallidus comb. nov. Int J Syst Evol Microbiol 54:2197-2201

Caccamo D, Gugliandolo C, Stackebrandt E, Maugeri TL (2000) Bacillus vulcani sp. nov., a novel thermophilic species isolated from a shallow marine hydrothermal vent. Int J Syst Evol Microbiol 50:2009-2012

Feitkenhauer H, Schnicke S, Müller R, Märk1 H (2003) Kinetic parameters of continuous cultures of Bacillus thermoleovorans sp. A2 degrading phenol at $65^{\circ} \mathrm{C}$. J Biotechnol 103:129-135

Feng L, Wang W, Cheng J, Ren Y, Zhao G, Gao C, Tang Y, Liu X, Han W, Peng X, Liu R, Wang L (2007) Genome and proteome of long-chain alkane degrading Geobacillus thermodenitrificans NG80-2 isolated from a deep-subsurface oil reservoir. Proc Natl Acad Sci USA 104: $5602-5607$

Griffin DW (2007) Atmospheric movement of microorganisms in clouds of desert dust and implications for human health. Clin Microbiol Rev 20:459-477

Haft DH, Selengut J, Mongodin EF, Nelson KE (2005) A guild of 45 CRISPR-Associated (Cas) protein families and multiple CRISPR/Cas subtypes exist in prokaryotic genomes. PLoS Comput Biol 1:474-483

Ishii Y, Konishi J, Okada H, Hirasawa K, Onaka T, Suzuki M (2000) Operon structure and functional analysis of the genes encoding thermophilic desulfurizing enzymes of Paenibacillus sp A11-2. Biochem Biophys Res Commun 270:81-88

Kim J-J, Masui R, Kuramitsu S, Seo J-H, Kim K, Sung M-H (2008) Characterization of growthsupporting factors produced by Geobacillus toebii for the commensal thermophile Symbiobacterium toebii. J Microbiol Biotechnol 18:490-496 
Marchant R, Banat IM, Rahman TJ, Berzano M (2002a) What are high-temperature bacteria doing in cold environments? Trends Microbiol 10:120-121

Marchant R, Banat IM, Rahman TJ, Berzano M (2002b) The frequency and characteristics of highly thermophilic bacteria in cool soil environments. Environ Microbiol 4:595-602

Marchant R, Sharkey FH, Banat IM, Rahman TJ, Perfumo A (2006) The degradation of $n$-hexadecane in soil by thermophilic geobacilli. FEMS Microbiol Ecol 56:44-54

Marchant R, Franzetti A, Pavlostathis SG, Okutman Tas D, Erdbrügger I, Únyayar A, Mazmanci MA, Banat IM (2008) Thermophilic bacteria in cool temperate soil environments: are they metabolically active or continually added by global atmospheric transport? Appl Microbiol Biotechnol 5:841-852

Nazina TN, Tourova TP, Poltaraus AB, Novikova EV, Grigoryan AA, Ivanova AE, Lysenko AM, Petrunyaka VV, Osipov GA, Belyaev SS, Ivanov MV (2001) Taxonomic study of aerobic thermophilic bacilli: descriptions of Geobacillus subterraneus gen. nov., sp. nov. and Geobacillus uzenensis sp. nov. from petroleum reservoirs and transfer of Bacillus stearothermophilus, Bacillus thermocatenulatus, Bacillus thermoleovorans, Bacillus kaustophilus, Bacillus thermoglucosidasius and Bacillus thermodenitrificans to Geobacillus as the new combinations G. stearothermophilus, G. thermocatenulatus, G. thermoleovorans, G. kaustophilus, G. thermoglucosidasius and G. thermodenitrificans. Int J Syst Evol Microbiol 51:433-446

Nazina TN, Lebedeva EV, Poltaraus AB, Tourova TP, Grigoryan AA, Sokolova DS, Lysenko AM, Osipov GA (2004) Geobacillus gargensis sp. nov., a novel thermophile from a hot spring, and the reclassification of Bacillus vulcani as Geobacillus vulcani comb. nov. Int J Syst Evol Microbiol 54:2019-2024

Newmark RL, Aines RD (1998) They all like it hot: faster cleanup of contaminated soil and groundwater. Sci Technol Rev May:4-11

Pavlostathis SG, Marchant R, Banat IM, Ternan N, McMullan G (2006) High growth rate and substrate exhaustion results in rapid cell death and lysis in the thermophilic bacterium Geobacillus thermoleovorans. Biotechnol Bioeng 95:84-95

Perfumo A, Banat IM, Marchant R, Vezzulli L (2007) Thermally enhanced approaches for bioremediation of hydrocarbon-contaminated soils. Chemosphere 66:179-184

Ratajczak A, Geißdörfer W, Hillen W (1998a) Alkane hydroxylase from Acinetobacter sp. strain ADP-1 is encoded by alkM and belongs to a new family of bacterial integral membrane hydrocarbon hydroxylases. Appl Environ Microbiol 64:1175-1179

Ratajczak A, Geißdörfer W, Hillen W (1998b) Expression of the alkane hydroxlase from Acinetobacter sp. strain ADP-1 is induced by a broad range of n-alkanes and requires the transcriptional activator alkR. J Bacteriol 180:5822-5827

Rhee SK, Lee SG, Hong SP, Choi YH, Park JH, Kim CJ, Sung MH (2000) A novel microbial interaction: obligate commensalism between a new gram-negative thermophile and a thermophilic Bacillus strain. Extremophiles 4:131-136

Rhee SK, Jeon CO, Bae JW, Kim K, Song JJ, Kim JJ, Lee SG, Kim HI, Hong SP, Choi YH, Kim SM, Sung MH (2002) Characterization of Symbiobacterium toebii, an obligate commensal thermophile isolated from compost. Extremophiles 6:57-64

Schäffer C, Franck WL, Scheberl A, Kosma P, McDermott TR, Messner P (2004) Classification of isolates from locations in Austria and Yellowstone National Park as Geobacillus tepidamans sp. nov. Int J Syst Evol Microbiol 54:2361-2368

Scholz T, Demharter W, Hensel R, Kandler O (1987) Bacillus pallidus sp. nov., a new thermophilic species from sewage. Syst Appl Microbiol 9:91-96

Sood N, Lal B (2008) Isolation and characterization of a potential paraffin-wax degrading thermophilic bacterial strain Geobacillus kaustophilus TERI NSM for application in oil wells with paraffin deposition problems. Chemosphere 70:1445-1451

Sung MH, Kim H, Bae JW, Rhee SK, Jeon CO, Kim K, Kim JJ, Hong SP, Lee SG, Yoon JH, Park YH, Baek DH (2002) Geobacillus toebii sp. nov., a novel thermophilic bacterium isolated from hay compost. Int J Syst Evol Microbiol 52:2251-2255 
Takami H, Nishi S, Lu J, Shinamura S, Takaki Y (2004a) Genomic characterization of thermophilic Geobacillus species isolated from the deepest sea mud of the Mariana Trench. Extremophiles 8: 351-356

Takami H, Takaki Y, Chee GJ, Nishi S, Shinamura S, Suzuki H, Matsui S, Uchiyama I (2004b) Thermoadaptation trait revealed by the genome sequence of thermophilic Geobacillus kaustophilus. Nucleic Acids Res 32:6292-6303

van Beilen JB, Panke S, Lucchini S, Franchini AG, Röthlisberger M, Witholt B (2001) Analysis of Pseudomonas putida alkane degradation gene clusters and flanking insertion sequences: evolution and regulation of the alk-genes. Microbiology 147:1621-1630

Whyte LG, Smits TH, Labbe D, Witholt B, Greer CW, van Beilen JB (2002) Gene cloning and characterisation of multiple alkane hydroxylase systems in Rhodococcus strains Q15 and NRR1. Appl Environ Microbiol 68:5933-5942 